\title{
The Role of Thoracic Ultrasonography in the Diagnosis of Anterior Mediastinal Lesions
}

\author{
Coşkun Doğan, Sevda Şener Cömert, Benan Çağlayan, \\ Elif Torun Parmaksız, Ali Fidan, Banu Salepçi
}

Department of Chest Diseases, Kartal Dr. Lütfi Kırdar Training and Research Hospital İstanbul, Turkey

Submitted: 01.08.2016 Accepted: 20.10 .2016

Correspondence: Coşkun Doğan, Department of Chest Diseases, Kartal Dr. Lütfi Kırdar Training and Research Hospital, İstanbul, Turkey E-mail: coskund24@hotmail.com

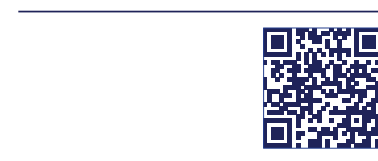

Keywords: Anterior mediastinal lesion, transthoracic fine needle aspiration biopsy; ultrasonography.

\begin{abstract}
Objective: The aim of the present study was to determine diagnostic success of thoracic ultrasonography (US)-guided transthoracic fine needle aspiration biopsy (TTFNAB) performed by chest physicians for anterior mediastinal lesions.
\end{abstract}

Methods: Patients with anterior mediastinal lesions observed with US-guided TTFNAB performed in our clinic between December 2010 and January 2016, were included in the study. Details of clinical, demographic, and radiographic findings of the patients, sonographic appearance and size of the lesions, diagnosis based on US-guided TTFNAB results, final diagnosis, method of final diagnosis, and complications were recorded. Thoracic US was performed by an experienced chest physician using Logiq 7 system (GE Healthcare, Inc. Chicago, IL, USA) with $3.5 \mathrm{MHz}$ convex transducer in abdominal mode.

Results: Fourteen patients with mean age of $47.5 \pm 13$ years were included in the study. Twelve cases (85.7\%) were diagnosed with US-guided TTFNAB. Remaining 2 (14.3\%) cases could not be diagnosed with this method. The final diagnosis in those 2 cases was squamous cell carcinoma and lymphoma. Lesions in study were both malignant $(n=12 ; 85.7 \%)$ and benign $(n=2 ; 14.3 \%)$. Sensitivity and specificity of US-guided TTFNAB were calculated as $85.7 \%$ and $100 \%$, respectively. Pneumothorax was observed in only I case.

Conclusion: US- guided TTFNAB is an easy, accessible, and inexpensive diagnostic method with high diagnostic efficiency, low complication rate, and no radiation exposure.

\section{INTRODUCTION}

Ultrasonography (US) is an imaging modality based on the reflection of sound waves directed at tissues with the aid of a transducer. Since different tissues reflect sound waves at various frequencies, images also demonstrate variations. Soft tissues transmit sound waves better, they are hypoechoic, and appear as dark image. Pulmonary parenchyma contains air, which dissipates ultrasound energy, so it is not well visualized on US. ${ }^{[1]}$

Mediastinal lesion can originate in anterior (54-57\%), middle (9.5-20\%), or posterior (26-33.4\%) mediastinum. Most frequently seen lesions of anterior mediastinum are thymoma, germ cell tumors (teratoma, seminoma, embryonal cell cancer, and choriocarcinoma), lymphoma, thyroid, and parathyroid lesions. In case of pulmonary car- cinoma, if mediastinum does not contain pathological mass lesion, US does not provide satisfactory image. However, pathological mass lesion that are enlarged and have extended up to the chest wall can be easily seen on sonogram. In these lesions, US is cost-effective imaging modality with higher sensitivity than conventional methods, such as chest X-ray, computed tomography (CT), or magnetic resonance imaging (MRI). Especially in cases of pathological lesion, like pericardial cyst or bronchogenic cyst, US discriminates very precisely between solid and cystic lesions. However, CT and MRI are more sensitive than US for imaging of posterior mediastinum, paravertebral, and retrosternal regions. Therefore, US- guided TTFANB is most often used for anterior mediastinal lesions. ${ }^{[2]}$

Greatest advantage of US-guided TTFNAB over TTFNAB performed with the aid of CT or fluoroscopy is lack of ra- 
diation exposure. In addition, because it is a real-time procedure, biopsy needle can be traced and manipulated to target lesion. Necrotic areas can be avoided and efficiency of the procedure can be increased. In mediastinal lesions, TTFNAB is usually performed with guidance of CT. However, in instance of very large anterior mediastinal tumors that have invaded the chest wall, US may be preferred for above-mentioned advantages. ${ }^{[3]}$

Present study was designed to examine characteristics of US-guided biopsies performed by chest physicians for anterior mediastinal lesions and to assess diagnostic success of US-guided TTFANB performed for mediastinal lesions.

\section{MATERIAL AND METHODS}

Medical files of 188 patients who underwent thoracic USguided TTFANBs performed by chest physicians in our hospital between December 2010 and January 2016 were retrospectively screened. Of those, files of I 4 patients with mediastinal mass lesion detected on posteroanterior chest radiogram and thoracic CT were selected for the study. Clinical and demographic data were recorded. Details of posteroanterior chest radiography, thoracic CT findings, thoracic US examination findings, sonographic appearance and dimensions of the lesion, frequency of applications, diagnosis based on thoracic US-guided TTFNAB, final diagnosis, and complications were recorded and analyzed. Routine informed consent forms were obtained from all patients.

\section{Thoracic ultrasound}

Thoracic US was performed by an experienced chest physician using Logiq 7 system (GE Healthcare, Inc. Chicago, IL, USA) with $3.5 \mathrm{MHz}$ convex transducer in abdominal mode. First, probe was placed bilaterally at intercostal

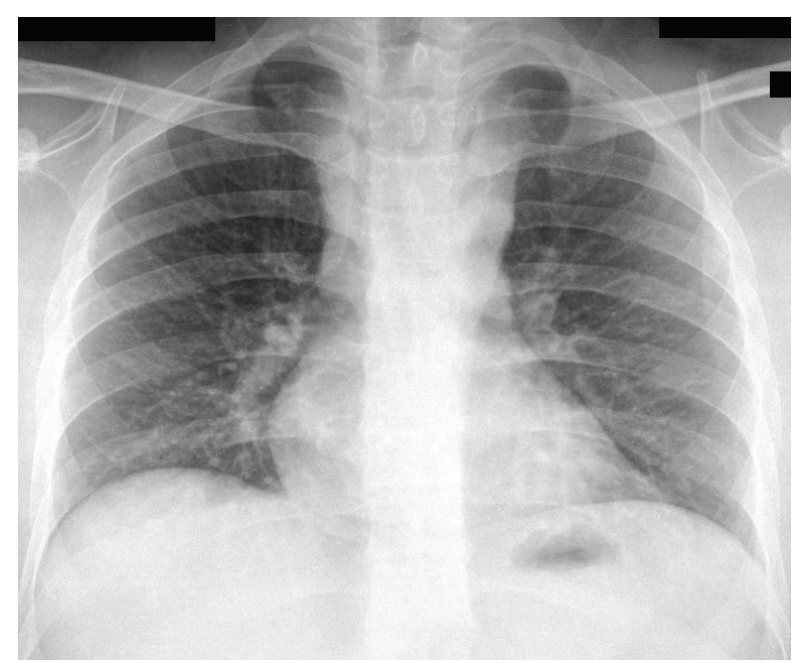

Figure 1. Anteroposterior chest $\mathrm{X}$-ray demonstrating mediastinal enlargement in a case with anterior mediastinal mass lesion.

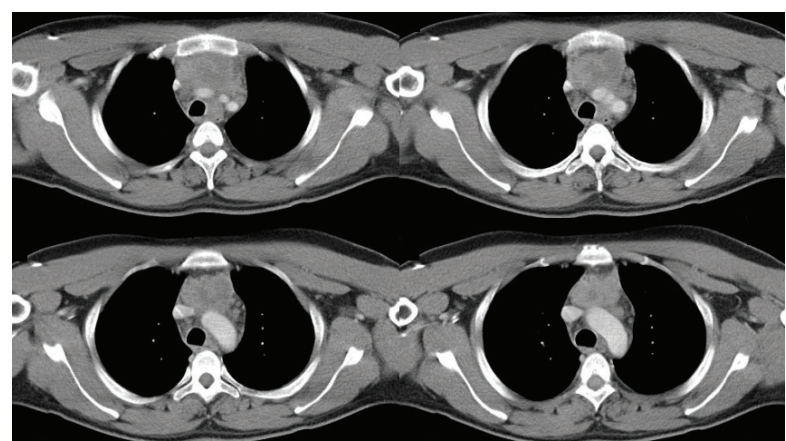

Figure 2. A mass lesion measuring nearly $10 \times 10 \mathrm{~cm}$ in close proximity to vascular structures and extending up to aortic arch, as visualized from mediastinal window in thoracic computed tomography.

space on the parasternal region, then entire mediastinal region, including parasternal, suprasternal, infrasternal, and subcostal regions, was screened. Afterward, the patient sat erect, or if necessary, was laid in supine, oblique, and lateral decubitus positions, and probe was moved along intercostal spaces in transverse and longitudinal directions using parasternal, suprasternal, or infrasternal-subcostal approach according to suspected location of the mass lesion until suitable region to be biopsied was identified. ${ }^{[4]}$ Thoracic US revealed sonographic appearance of identified lesion, dimensions of lesion, and distance from subcutaneous layer to lesion. Region within lesion where needle can be manipulated was measured. Vascular structures within and in vicinity of area to be biopsied were detected using color Doppler mode of the device (Figures I-4).

\section{Transthoracic ultrasound-guided biopsy procedure}

Respiratory function test was performed before procedure. Whole blood, biochemical, and coagulometric test results were analyzed. TTFNAB was not performed in cases with preprocedural platelet count $<50.000 / \mu \mathrm{L}$ or international normalized ratio $>1.3$. US-guided TTFNAB was performed while the patient sat erect, or when necessary, patient was laid in supine, oblique, and lateral decubitus positions, and probe was moved along intercostal spaces and in transverse and longitudinal directions using parasternal, suprasternal, or infrasternal-subcostal approach according to suspected location of the mass lesion using free-hand technique or indirect technique. No premedication or sedation was administered to patients before procedure. lodine-alcohol was used to disinfect the region of application, and US probe sterilized. Predetermined area with measured dimensions was screened with color Doppler probe and 22-G spinal needle mounted to $20 \mathrm{~mL}$ injector was used for biopsy. Upon reaching target lesion, tissue samples were aspirated from various points, rotating needle in a circle. Once aspiration of visible or hemorrhagic material into the syringe was confirmed, pro- 

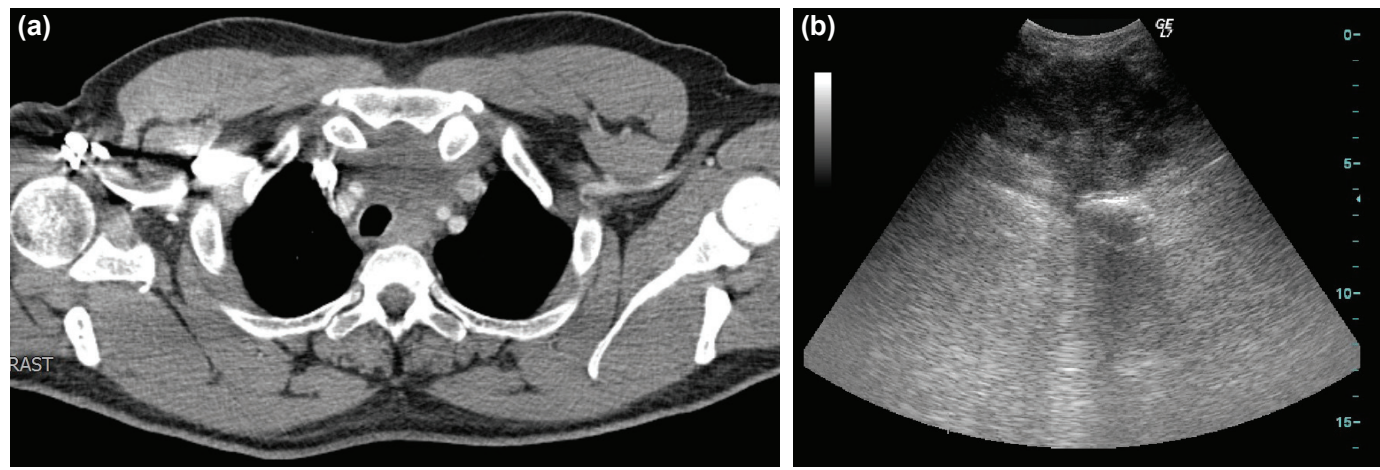

Figure 3. (a) An anterior mediastinal mass lesion surrounding the trachea, measuring nearly $6 \times 5 \mathrm{~cm}$; (b) Sonographic appearance of the same lesion from suprasternal approach was hypoechoic mass lesion with patchy areas of necrosis.
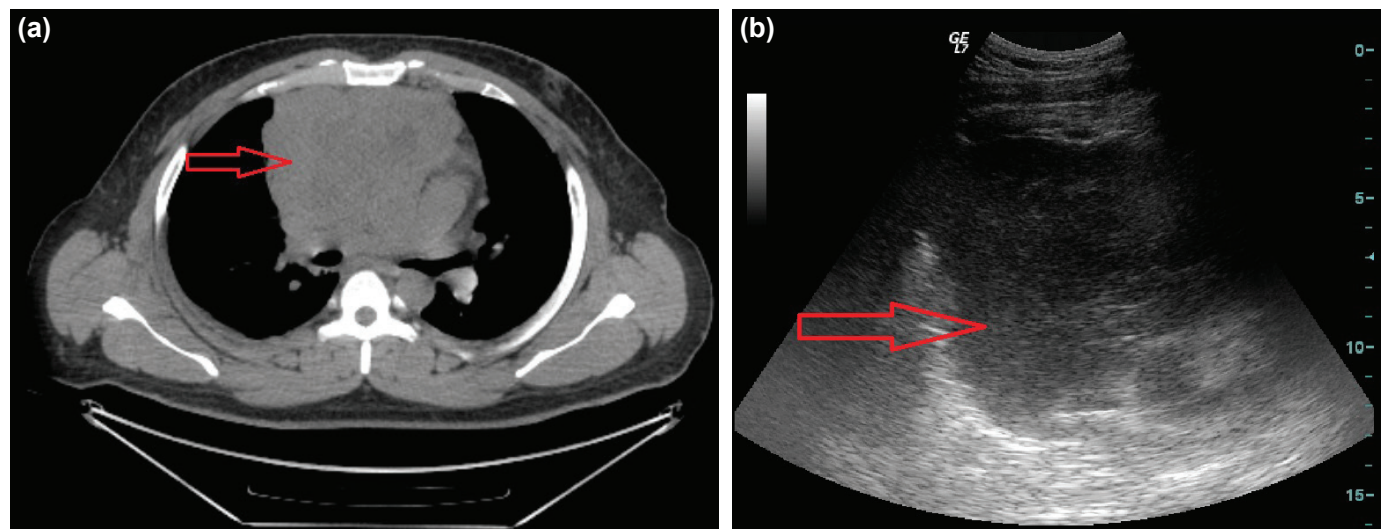

Figure 4. (a) A mass lesion measuring nearly $10 \times 10 \mathrm{~cm}$ (red arrow); (b) Sonographic appearance of the same lesion from suprasternal approach was hypoechoic mass lesion with irregular contours.

cedure was terminated. Real-time procedure was performed without on-site pathologist. Aspirated material was placed on slide and fixed with $95 \%$ alcohol, and material remaining in syringe was embedded in paraffin blocks and sent to pathology laboratory. ${ }^{[5]}$

\section{Statistical Analysis}

Statistical analysis was performed using SPSS Statistics for Windows, Version 17.0. (SPSS Inc., Chicago, IL, USA) software. Descriptive statistics of continuous variables were expressed as mean $\pm S D$, and categorical variables as percentages.

\section{RESULTS}

Total of I 88 cases underwent US-guided TTFNAB at our facility during the study period. Among them, 14 cases with anterior mediastinal mass lesion were detected, and these were included in the study. Mean age of 14 patients (female, $n=8,57.1 \%$; male, $n=6,42.9 \%$ ) who were enrolled was $47.5 \pm 13$ years (range: $26-70$ years). Clinical, demographic, and radiological data are provided in Table $I$. Mean long- and short-axis diameter of mass lesions were
$67.0 \pm 22.3 \mathrm{~mm}$ and $55.4 \pm 22.2 \mathrm{~mm}$, respectively. Examination of sonographic echopatterns revealed presence of hypoechoic $(n=13 ; 92.8 \%)$, and hyperechoic $(n=1 ; 7.2 \%)$ lesions. Homogenous $(n=12 ; 85.7 \%)$ and heterogeneous $(n=2 ; 14.3 \%)$ lesions containing necrotic areas were detected. Ten (7I.4\%) mass lesions had smooth contours, while 4 (28.6\%) were irregular. Thoracic US-guided TTFNAB diagnosed $12(85.7 \%)$ of 14 cases, and could not be used to diagnose $2(14.3 \%)$ cases. One of these undiagnosable cases was diagnosed as squamous cell carcinoma based on endobronchial US, and the other was diagnosed as lymphoma based on histopathological examination of surgical biopsy specimen. Cases were both malignant $(n=12$; $85.7 \%)$ and benign $(n=2 ; 14.3 \%)$ disease. Sensitivity, specificity, and positive and negative predictive values of thoracic US-guided TTFNAB were calculated to be $85.7 \%, 100 \%$, $100 \%$, and $14 \%$, respectively. For each lesion, average of $1.2 \pm 0.4$ procedures were performed, and with exception of one $(7.2 \%)$ case of minimal pneumothorax, which did not require intubation of chest tube, no complication occurred. Mean duration of biopsy procedure for each patient was calculated to be $15.8 \pm 3.9$ minutes. Diagnoses made using US-guided biopsies are presented in Table 2. 
Table I. Demographic, clinical, and radiological characteristics of the patients

\begin{tabular}{|c|c|c|}
\hline & $\begin{array}{l}\text { Patients } \\
(n=14)\end{array}$ & $\%$ \\
\hline Age (years), mean $\pm S D$ & $47.5 \pm 13$ & - \\
\hline \multicolumn{3}{|l|}{ Gender (n) } \\
\hline Female & 8 & 57.1 \\
\hline Male & 6 & 42.9 \\
\hline \multicolumn{3}{|l|}{ Smoking history } \\
\hline Smokers & 8 & 57.1 \\
\hline Non-smokers & 6 & 42.9 \\
\hline Mean pack year $\pm S D$ & $9.9 \pm 14.3$ & - \\
\hline \multicolumn{3}{|l|}{ Comorbidities } \\
\hline Present & 10 & 71.5 \\
\hline Absent & 4 & 28.5 \\
\hline \multicolumn{3}{|l|}{ Symptoms } \\
\hline Chest and back pain & 8 & 57.1 \\
\hline Shortness of breath & 6 & 42.8 \\
\hline Coughing & 5 & 35.7 \\
\hline Lassitude & 4 & 28.5 \\
\hline Swelling of neck/face & 3 & 21.4 \\
\hline Weight loss & 3 & 21.4 \\
\hline Hemoptysis & I & 7.2 \\
\hline \multicolumn{3}{|l|}{ Posterioanterior chest X-ray } \\
\hline Mediastinal enlargement & 12 & 85.7 \\
\hline Parenchymal mass & 2 & 14.2 \\
\hline Parenchymal nodule & 3 & 21.4 \\
\hline Pleural fluid & I & 7.2 \\
\hline Consolidation & 1 & 7.2 \\
\hline \multicolumn{3}{|l|}{ Thoracic computed tomography } \\
\hline Mediastinal mass & 14 & 100 \\
\hline Atelectasia & 3 & 21.4 \\
\hline Parenchymal nodule & 2 & 14.2 \\
\hline Parenchymal mass & I & 7.2 \\
\hline Pleural fluid & I & 7.2 \\
\hline Consolidation & I & 7.2 \\
\hline
\end{tabular}

SD: Standard deviation.

\section{DISCUSSION}

This study was designed to draw attention to use of thoracic US-guided TTFNAB as a diagnostic tool and to investigate diagnostic success. In 12 (85.7\%) of 14 cases with anterior mediastinal lesion detected with thoracic US, diagnosis with thoracic US-guided biopsy was successful. Sensitivity and specificity of thoracic-US guided TTFNAB was $85.7 \%$ and $100 \%$, respectively.
Table 2. Distribution of cases diagnosed with thoracic ultrasound

\begin{tabular}{lcc}
\hline & $\begin{array}{c}\text { Cases } \\
(\mathbf{n}=\mathbf{1 4})\end{array}$ & $\%$ \\
\hline Thymoma & 4 & 28.5 \\
Lymphoma & 2 & 14.2 \\
Non-small cell carcinoma & 2 & 14.2 \\
Thymic hyperplasia & $\mathrm{I}$ & 7.1 \\
Thymic cyst & $\mathrm{I}$ & 7.1 \\
Teratocarcinoma & $\mathrm{I}$ & 7.1 \\
Small cell carcinoma & $\mathrm{I}$ & 7.1 \\
Undiagnosed & 2 & 14.2 \\
\hline
\end{tabular}

Anterior mediastinum is bounded anteriorly by the sternum, posteriorly by the pericardium, and contains anatomical structures including thymus, aorta and its branches, major vessels, lymphatics, and adipose tissue. ${ }^{[6]}$ Apart from these organs, soft tissue lesions seen in the anterior mediastinum are almost always pathological, and excluding vascular abnormalities, histopathological examination is required to establish diagnosis. For diagnosis of mediastinal diseases, invasive surgical procedures, such as sternotomy, thoracotomy, parasternal anterior mediastinostomy, and video-assisted thoracoscopic surgery may be used. ${ }^{[7]}$ Studies performed have demonstrated that median rate of postoperative morbidity and mortality related to abovementioned surgical interventions was nearly $17 \%$ and $6 \%$, respectively. ${ }^{[8]}$ Though these rates may not be considered high for surgical intervention, they are above those observed in noninvasive diagnostic procedures with equivalent diagnostic effectiveness. Furthermore, when preoperative hospitalization and postoperative monitoring of the patient are taken into consideration, surgical costs rise significantly. Ayan et al. ${ }^{[9]}$ reported complication rate of II\% (atelectasia, $\mathrm{n}=\mathrm{I}$; diaphragmatic elevation, $\mathrm{n}=\mathrm{I}$; myasthenic crisis, $n=I$ ) in surgical interventions performed in 27 patients with mediastinal mass lesion. In our series, complication rate was $7.1 \%$ (only I case of pneumothorax, which did not require implantation of chest tube). Higher morbidity and mortality rates, and increased cost led us to use less invasive diagnostic methods, such as endobronchial US-guided transbronchial biopsy, CT-guided TTFNAB, and US-guided TTFNAB. Rubens et al. ${ }^{[10]}$ reported success rate of $96 \%$ with TTFNAB performed for 25 mediastinal masses. In their article, they emphasized that when compared with CT-guided TTFNAB, US-guided TTFNAB has many advantages, including real-time application, easy applicability, rapid turnaround time, more comfortable positioning of the patients, avoiding vascular injury due to use of Doppler signals and intravenous contrast material, lower cost, and shorter procedural time. Although this 
study revealed many advantages of US-guided TTFNAB, one of the most important advantages of this method is cost-effectiveness. Rubens et al. ${ }^{[10]}$ reported that for each patient biopsied, US-guided TTFNAB cost $25 \%$ less than CT-guided TTFNAB. Another advantage of US-guided TTFNAB they reported was median procedural time of 27 minutes; however, detailed information about procedural time was not provided. Sheth et al. ${ }^{[1]]}$ compared CT- and US-guided biopsies in total of 86 cases (US-guided TTFNAB, $n=34$; CT-guided TTFNAB, $n=52$ ) and calculated average duration of 45.2 and 31.4 minutes, respectively. In our study of US-guided TTFNAB, we calculated mean time interval between subcutaneous insertion of needle until withdrawal of needle after completion of aspiration to be 15.8 \pm 3.9 minutes. Decision to performing procedure after US evaluation of the patient likely contributed to shorter procedural time, especially in larger mass lesions localized at distance from vascular structures.

Morrisey et al. ${ }^{[12]}$ performed study with 94 cases with mediastinal mass lesion, and demonstrated advantages of USguided TTFNAB relative to CT-guided TTFNAB of ability to perform the former within a shorter time, and on realtime basis. However, they noted that for US-guided biopsy procedure, mediastinal mass should be large enough and localized on the chest wall, without interposition of aerated lung tissue. In their study, anterior mediastinal masses (total $n=36)$ were both benign $(n=15 ; 41.6 \%)$ and malignant $(n=21 ; 58.4 \%)$ lesions. Most frequently diagnosed malignant lesions were carcinoma, lymphoma, and thymoma, and benign lesions, in order of frequency, were thyroid, cyst, and nonspecific inflammation. In our study, final diagnosis was made for $85.7 \%$ of malignant lesions and $14.3 \%$ of benign lesions using US technique. Thymoma $(n=4$; $28.5 \%$ ) was most frequently detected malignancy. This result was not consistent with literature findings, as we included CT- and fluoroscopy-guided biopsy results in our study. We were also very selective, especially with regard to size of lesion when we decided to perform thoracic USguided TTFNAB due to fear regarding procedural safety and potential complications. Another reason might be our preference for US-guided TTFNAB for large lesions and different method, such as CT-guided TTFNAB for smaller lesions. In the present series, mean long-axis diameter of lesions was $67 \pm 22.3 \mathrm{~mm}$, while mean short-axis diameter was $55.4 \pm 22.2 \mathrm{~mm}$, which may affect diagnostic success rate of procedure. On this issue, Sheth et al. ${ }^{\left[{ }^{11}\right]}$ compared US-guided TTFNAB and CT-guided TTFNAB in total of 86 cases. They performed US-guided TTFNAB in 34, and CTguided TTFNAB in 52 cases. They reported median lesion diameter of $4.3 \mathrm{~cm}$ in US-guided TTFNAB procedures, and $2.9 \mathrm{~cm}$ in CT-guided TTFNAB procedures.

Many factors affect success rate of TTFNAB used in cases of mediastinal mass, including location and dimensions of lesion, presence of on-site pathologist, histopathological characteristics of lesion (epithelial tumor or hematological malignancy), clinical state of the patient, presence of comorbidities, and experience of the surgeon. ${ }^{[3]}$ Sensitivity of TTFNAB in mediastinal lesion, especially for epithelial lesion, ranges between $84 \%$ and $100 \%$; however, it drops to $42 \%$ to $82 \%$ in lymphoma. ${ }^{[13,14]}$ In our series, 2 (14.2\%) cases were diagnosed as lymphoma. One of our undiagnosed cases was diagnosed as lymphoma based on histopathological examination of surgical biopsy specimen. Difficulties may occur during establishment of diagnosis based on fine needle aspiration biopsy specimens, despite immunohistochemical staining and cellular block techniques. Our experiences favor use of US-guided Tru-Cut (Becton, Dickinson, Franklin Lakes, NJ, USA) biopsy rather than fine needle in cases with suspected lymphoma based on clinico-radiological examination results.

One of the limitations of our study is retrospective design. Study encompassed a long interval from December 2010 to January 2016. Early in the study, until our procedural experience matured, we were very selective with regard to tumor size in particular, and for smaller tumors we preferred to use other methods, which might have affected diagnostic success rate.

In conclusion, during our study, the writing process of this article, and review of relevant literature, advantages of US-guided TTFNAB compared with other diagnostic procedures were demonstrated, including fact that it is cost-effective method with higher diagnostic yield and lower complication rate without radiation exposure. In addition, chest physician can perform this technique alone using free-hand technique. This minimally invasive and minimally traumatic real-time technique can also be applied within shorter timeframe. Using this method, cavities and necrotic regions can be avoided, and it aids in collection of biopsy material from non-necrotic wall of the tumor. This is a reproducible technique that can be manipulated during biopsy with very little morbidity and mortality. ${ }^{[15-19]}$ In selected cases, US-guided TTFNAB can be a valuable alternative for anterior mediastinal lesions.

Authorship contributions

Concept: C.D.; Design: B.Ç.; Data collection \&/or processing: S.Ş.C.; Analysis and/or interpretation: E.T.P.; Literature search: B.S., A.F.; Writing: C.D.; Critical review: A.F.

Conflict of interest

None declared.

\section{REFERENCES}

1. Kilı̧̧aslan A, Topal A, Erol A, Gök F. Ultrasonographic Assessment of the Airway Anatomy and Clinical Use. Selçuk Tip Dergisi 2015;31:88-94.

2. Wernecke K, Diederich S. Sonographic features of mediastinal tumors. AJR Am J Roentgenol 1994;163:1357-64. [CrossRef] 
3. Düzgün F, Tarhan S. Perkütan transtorasik akciğer ve kemik biyopsileri. Trd Sem 2015;3:182-91. [CrossRef]

4. Kıral N. Mediasten. In: Çağlayan B, editör. Klinik uygulamada toraks ultasonografisi. İstanbul: Pubbiz; 2010. s. 31-7.

5. Cömert SŞ, Çağlayan B, Salepçi B, Fidan A, Parmaksız ET. The diagnostic value of ultr asound guided transthoracic needle aspiration in superior sulcus tumors. İzmir Göğüs Hastanesi Dergisi 2013;27:41-8.

6. Ödev K. Mediasten hastalıkları. In: Ödev K, editör. Toraks Radyolojisi. İstanbul: Nobel tıp kitabevi; 2005. s. 307-41.

7. Date H. Diagnostic strategies for mediastinal tumors and cysts. Thorac Surg Clin 2009;19:29-35. [CrossRef]

8. Davids RD, Oldham HN, Sabiston DC. The Mediastinum. In: Sabiston\&Spencer Surgery of the chest. 6th ed. Philadelphia: WB Saunders Co; 1996. pp. 576-611.

9. Ayan E, Balcı AE, Özalp K, Duran M, Vuraloğlu S, Çekirdekçi A. Mediastinal masses: review of 27 cases. Türk Göğüs Kalp Damar Cer Derg 2005;13:127-30.

10. Rubens DJ, Strang JG, Fultz PJ, Gottlieb RH. Sonographic guidance of mediastinal biopsy: An effective alternative to CT guidance. AJR Am J Roentgenol 1997;169:1605-10. [CrossRef]

11. Sheth S, Hamper UM, Stanley DB, Wheeler JH, Smith PA. US guidance for thoracic biopsy: A valuable alternative to CT. Radiology
1999;210:721-6. [CrossRef]

12. Morrisey B, Adams H, Gibbs AR, Crane MD. Percutaneous needle biopsy of the mediastinum: review of 94 procedures. Thorax 1993;48:632-7. [CrossRef]

13. Yu CJ, Yang PC, Chang DB, Wu HD, Lee LN, Lee YC, et al. Evaluation of ultrasonically guided biopsies of mediastinal masses. Chest 1991;100:399-405. [CrossRef]

14. Caremani M, Benci A, Tacconi D, Occhini U, Lapini L, Caremani A. Sonographic management of mediastinal syndrome. J Ultrasound 2009;12:61-8. [CrossRef]

15. Bernardino ME. Percutaneous biopsy. AJR 1984;142:41-5. [CrossRef]

16. Ikezoe J, Sone S, Higashihara T, Morimoto S, Arisawa J, Kuriyama $\mathrm{K}$. Sonographically guided needle biopsy for diagnosis of thoracic lesions. AJR 1984;143:229-34. [CrossRef]

17. Adler OB, Rosenberger A, Peleg H. Fine-needle aspiration biopsy of mediastinal masses: evaluation of 136 experiences. AJR Am J Roentgenol 1983;140:893-6. [CrossRef]

18. Wang HC, Yu CJ, Chang DB, Yuan A, Lee YC, Yang PC, et al. Transthoracic needle biopsy of thoracic tumours by a colour Doppler ultrasound puncture guiding device. Thorax 1995;50:1258-63. [CrossRef]

19. Anderson T, Lindgren PG, Elvin A. Ultrasound Guided thoracotomy and mediastinoscopy. Acta Radiologica 1992;33:423-6. [CrossRef]

\section{Ön mediasten Yerleşimli Lezyonların Tanısında Toraks Ultrasonografisi}

Amaç: Çalışmanın amacı göğüs hastalıkları uzmanları tarafından ön mediastinal kökenli lezyonlarda toraks ultrasonografisi (USG) rehberliğinde yapılan transtorasik ince iğne aspirasyon biyopsisinin (TTIAB) tanısal başarısını ortaya koymaktır.

Gereç ve Yöntem: Aralık 20I0-Ocak 2016 tarihleri arasında kliniğimizde USG rehberliğinde TTiAB yapılan tüm olgular içersinden ön mediasten yerleşimli lezyonu olan olgular çalışmaya alındı. Olguların klinik, demografik, radyolojik bulguları, lezyonların sonografik görünüm ve boyutları, USG eşliğinde yapılan TTIAB ile gelen tanıları, final tanıları, final tanı yöntemleri ve komplikasyonlar kayıt edildi. Toraks USG deneyimli göğüs hastalıkları uzmanı tarafından General Electric Logic 7 ile $3.5 \mathrm{MHz}$ konveks prob abdominal modda kullanılarak yapıldı.

Bulgular: Çalışmaya yaş ortalaması $47.5 \pm$ I 3 yıl olan 14 olgu alındı. Olguların I2'sine (\%85.7) tanı konuldu, iki (\% I4.3) olgu bu yöntemle tanı almadı. Tanı alamayan bu iki olgunun final tanısı skuamöz hücreli karsinom ve lenfoma idi. Olguların I2'si (\%85.7) malign, ikisi (\%।4.3) benign tanı aldı. İşlemin duyarlılı̆ı \%85.7 özgüllüğü \% 100 olarak hesaplandı. Lezyon başına ortalama I.2 20.4 kez işlem yapıldı, hasta başına ayrılan süre I5.8 3.9 dakika hesaplanmış olup bir olguda (\%7.2) minimal pnömotoraks dışında komplikasyon olmadı.

Sonuç: Ultrasonografisi rehberliğinde yapılan TTIAB’ler kolay, ulaşılabilir, ucuz, tanısal verimliliği yüksek, komplikasyon oranı düşük ve radyasyon maruziyeti olmayan bir yöntemdir.

Anahtar Sözcükler: Ön mediasten lezyonları; trans-toasik ince iğne aspirasyon biyopsi; ultasonografi. 